\title{
Efficacy of Pulse Steroid Therapy in Acute Viral Encephalopathy (Case Report)
}

\section{Barış Adakli ${ }^{*}$ Nedim Çekmen and Tolga Tezer}

Department of Anesthesiology and Intensive Care, Güven Hospital, Turkey

*Corresponding author: Barış Adakli, Department of Anesthesiology and Intensive Care, Güven Hospital, Hüseyin Rahmi sok 8/6, Turkey, Tel: (90)05336122066; Email: badakli@hotmail.com

Rec date: Apr 17, 2016; Acc date: May 24, 2016; Pub date: May 26, 2016

Copyright: (C) 2016 Adakli B, et al. This is an open-access article distributed under the terms of the Creative Commons Attribution License, which permits unrestricted use, distribution, and reproduction in any medium, provided the original author and source are credited.

\begin{abstract}
Viral encephalopathy is a very rare, but a serious neurologic condition. We present a patient who was admitted to our hospital because of drowsiness, memory disturbances, non-compliance, and disorientation. Treatment with methylprednisolone pulse treatment facilitated recovery without severe sequela. Therefore; when acute viral encephalopathy is actually suspected, steroid pulse therapy should be considered during the treatment.
\end{abstract}

Keywords: Encephalitis; Pulse steroid therapy; MRI

\section{Introduction}

Encephalopathy corresponds to an inflammation of the brain parenchyma caused by both infectious (influenza A, HHV6, HSV, VZV, measles) and non-infectious diseases (limbic encephalitis, Rasmussen's syndrome, metabolic diseases). Viruses are the most common infectious agents associated with acute encephalitis. İn developed countries, HSV type 1 is the most common sporadic encephalitis reason in adults and varicella zoster virus (VZV) is responsible nearly $22 \%$ of paediatric cases. The main symptoms are fever, altered level of consciousness, headache, focal neurological deficits and seizure. Noteworthy, about $70 \%$ of viral encephalitis cases remain of unknown origin, even with modern laboratorial techniques $[1]$

In our case, we present an unknown virus infection associated with a rapid recovery of encephalopathy with successful treatment of steroid pulse therapy and aim to discuss this case in company with literature.

\section{Case Report}

A 65 years old woman was admitted to our hospital because of drowsiness, memory disturbance, un-cooperation and disorientation. Her comorbidities were hypertension, hypothyroidis, vertigo and rheumatoid arthritis. The medication she had taken was $50 \mathrm{mg}$ tenoretic (atenolol+chlorthalidone), $200 \mathrm{mg}$ plaquenil (hydroxicloroquine), $50 \mu \mathrm{g}$ euthyrox (levothroxine), $24 \mathrm{mg}$ betaserc (betahistine dihydrochloride) and $100 \mathrm{mg}$ corasprin (acetylsalicylicacid) also she had already been taking $1500 \mathrm{mg} /$ day klovirex (acyclovir) and $1600 \mathrm{mg} /$ day brufen (ibuprofen) for three days because of her grippal symptoms.

On admission, neurological examination revealed the following; she was confused, un-cooperated, disoriented and Glascow Coma Scale (GCS) was of 11/15, Acute Physiology and Chronic Health Evaluation II (APACHE II): 20, Multiple Organ Dysfunction Score (MODS): 5, Sequential Organ Failure Assessment (SOFA): 5. Her left pupil was reactive to the light but right pupil reaction was reduced. Deep tendon reflexes were normal and there were no motor deficits. Her physical examination revealed the following; body temperature $37.8^{\circ} \mathrm{C}$ (centigrade degree), blood pressure 138/63 mmHg, pulse rate 95 beats/ min, regular, respiration rate $18 / \mathrm{min}$, peripheral oxygen saturation $\left(\mathrm{sPO}_{2}\right) 98 \%$ on room air, arterial blood gas; $\mathrm{PO}_{2}: 66 \mathrm{mmHg}, \mathrm{pCO}_{2}$ : $28.2 \mathrm{mmHg}, \mathrm{sPO}_{2}: 96.7 \%, \mathrm{pH}: 7.53, \mathrm{HCO}_{3}: 23.6$, Be: $1.0 \mathrm{Mmol} / \mathrm{L}$. Laboratory findings are shown in Table 1 . There were no abnormal findings. On the second day of her admission, leukocytosis with neutropile and AST, BUN, creatinine, glucose, LDH, CRP and d-dimer were increased which are shown in Table 2.

\begin{tabular}{|l|l|}
\hline \multicolumn{2}{|l|}{ Laboratory findings (day 0 ) } \\
\hline WBC & $75600 / \mu \mathrm{L}$ \\
\hline Neutrophils & $67.0 \%$ \\
\hline Lymphocytes & $20.2 \%$ \\
\hline Eosinophils & $0.16 \%$ \\
\hline Basophils & $0.8 \%$ \\
\hline Monocyte & $11.8 \%$ \\
\hline RBC & $518 \times 104 / \mu \mathrm{L}$ \\
\hline Hgb & $13.2 \mathrm{~g} / \mathrm{dL}$ \\
\hline Hct & $40.4 \%$ \\
\hline Platelets & $229 \times 103 / \mu \mathrm{L}$ \\
\hline AST & $19 \mathrm{U} / \mathrm{L}$ \\
\hline ALT & $13 \mathrm{U} / \mathrm{L}$ \\
\hline LDH & $213 \mathrm{U} / \mathrm{L}$ \\
\hline Albumin & $4.1 \mathrm{~g} / \mathrm{L}$ \\
\hline Glucose & $104 \mathrm{mg} / \mathrm{dL}$ \\
\hline BUN & $18 \mathrm{mg} / \mathrm{dL}$ \\
\hline Creatinine & $0.7 \mathrm{mg} / \mathrm{dL}$ \\
\hline Procalcitonin & $<0.05 \mathrm{ng} / \mathrm{mL}$ \\
\hline
\end{tabular}


Page 2 of 3

\begin{tabular}{|l|l|}
\hline Total bilirubin & $0.76 \mathrm{mg} / \mathrm{dL}$ \\
\hline $\mathrm{Na}$ & $138 \mathrm{mEq} / \mathrm{L}$ \\
\hline $\mathrm{K}$ & $3.16 \mathrm{mEq} / \mathrm{L}$ \\
\hline $\mathrm{Cl}$ & $100.5 \mathrm{mEq} / \mathrm{L}$ \\
\hline CRP & $1.65 \mathrm{mg} / \mathrm{L}$ \\
\hline ST3 & $3.3 \mathrm{pmol} / \mathrm{L}$ \\
\hline ST4 & $18.8 \mathrm{pmol} / \mathrm{L}$ \\
\hline TSH & $0.48 \mathrm{U} / \mathrm{mL}$ \\
\hline CSF cell count & rare leukocytes \\
\hline Protein & $62.4 \mathrm{~g} / \mathrm{dL}$ \\
\hline Glucose & $59 \mathrm{mg} / \mathrm{dL}$ \\
\hline
\end{tabular}

Table 1: Laboratory findings (day 0).

\begin{tabular}{|c|c|}
\hline \multicolumn{2}{|c|}{ Laboratory findings (day 2) } \\
\hline WBC & $134000 / \mu \mathrm{L}$ \\
\hline Neutrophils & $82.5 \%$ \\
\hline Lymphocytes & $7.34 \%$ \\
\hline Eosinophils & $0.01 \%$ \\
\hline Basophils & $0.4 \%$ \\
\hline Monophils & $9.7 \%$ \\
\hline RBC & $448 \times 104$ \\
\hline $\mathrm{Hgb}$ & $11.2 \mathrm{~g} / \mathrm{dL}$ \\
\hline Hct & $35.4 \mathrm{~g} / \mathrm{dL}$ \\
\hline Platelet & $190 \times 103 / \mu \mathrm{L}$ \\
\hline AST & $46 \mathrm{U} / \mathrm{L}$ \\
\hline ALT & $22 \mathrm{U} / \mathrm{L}$ \\
\hline LDH & $397 \mathrm{U} / \mathrm{L}$ \\
\hline Albumin & $3.2 \mathrm{~g} / \mathrm{L}$ \\
\hline Glucose & $162 \mathrm{mg} / \mathrm{dL}$ \\
\hline BUN & $36.9 \mathrm{mg} / \mathrm{dL}$ \\
\hline Creatinine & $3.8 \mathrm{mg} / \mathrm{dL}$ \\
\hline Pro-calcitonin & $1.58 \mathrm{ng} / \mathrm{mL}$ \\
\hline Total bilirubin & $0.2 \mathrm{mg} / \mathrm{dL}$ \\
\hline $\mathrm{Na}$ & $144 \mathrm{mEq} / \mathrm{L}$ \\
\hline $\mathrm{K}$ & $4.2 \mathrm{mEq} / \mathrm{L}$ \\
\hline $\mathrm{Cl}$ & $109.8 \mathrm{mEq} / \mathrm{L}$ \\
\hline CRP & $151 \mathrm{mg} / \mathrm{L}$ \\
\hline
\end{tabular}

\begin{tabular}{|l|l|}
\hline D-dimer & $522.6 \mathrm{ng} / \mathrm{mL}$ \\
\hline
\end{tabular}

Table 2: Laboratory findings (day 2).

On admission, brain computerized tomography (CT) was normal. Follow up brain magnetic resonance imaging (MRI) study showed slightly high signals in the basal cisternas with thickening of the dural surfaces on the fluid-attenuated inversion-recovery (FLAIR) images but no abnormal signal in diffusion weighted imaging (DWI), T2W1, T1W1 and enhanced T1W1 (Figure 1). Electrocardiogram and the chest radiography showed no significant changes. Electroencephalogram showed normal basic activity without epileptiform discharges. Analysis of cerebrospinal fluid (CSF) showed high protein levels with normal glucose level and no pleocytosis. Hepatitis (HBsAg, AntiHBs, HCV) and HIV 1-2 antibodies were negative. İmmunoglobuline profile (HSV tip 1/2-IgG/M, CMV IgG/M) and CMV DNA was negative. Septic screening including nasopharyngeal aspiration, blood, sputum and urine cultures, CSF gram stain and culture were normal. No pathogens that might cause meningitis (Herpes simplex virus, Ebstein bar virus, Cytomegalovirus) were detected by multiplex polimerase chain reaction (PCR) in her CSF samples.

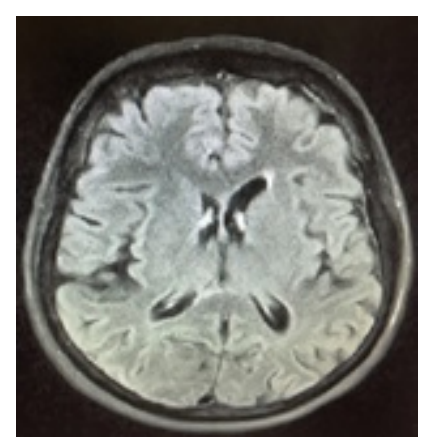

Figure 1: Slightly high signals in the basal cisternas with the thickening of dural surfaces on FLAIR images.

On the first day of her admission, she was still not able to talk with her family and did not get well by feeding nutrition, acyclovir (1500 $\mathrm{mg}$ /day) and supportive treatments like low molecular weight heparin (LMWH) in case of an embolism. She was still confused, uncooperated, and disoriented. GKS: 9, APACHE II: 23, MODS: 6, SOFA: 6. Her pupils were bilateral reactive to the light. According to her physical examination; body temperature $36.8^{\circ} \mathrm{C}$, blood pressure $150 / 85$ $\mathrm{mmHg}$, pulse rate 170 beats/min, respiratory rate $24 / \mathrm{min}, 90 \% \mathrm{sPO}_{2}$ with the $4 \mathrm{~L} / \mathrm{min}$ nasal $\mathrm{O}_{2}$, deep metabolic acidosis and hypoxemia on the arterial blood gas, she was electively intubated although noninvasive mechanic ventilation had been performing.

On the 2nd day we started to treat her with IV methylprednisolone pulse therapy $(1000 \mathrm{mg}$ /day within $100 \mathrm{ml}, 0.9 \% \mathrm{NaCl}$ approximately in half an hour) under the diagnosis of suspected viral encephalopathy. On the 5th day after the three day methylprednisolone treatment she was extubated and able to speak, oriented and cooperated. On the 10th day, her MRI showed persistent thickening but reduced contrast agent uptake on dural surfaces and subdural hygroma on the right frontal lobe with mild cerebellar atrophy (Figure 2) she was discharged from 
intensive care unit to neurology department with mild disturbance in her gait.

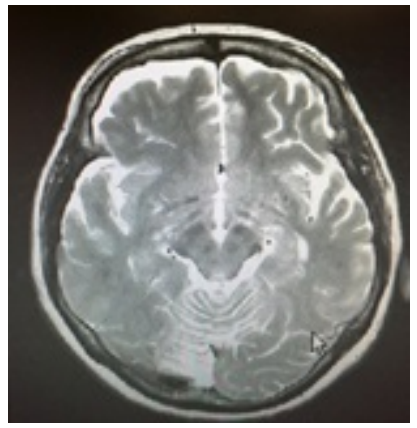

Figure 2: Persistant thickening on dural surfaces and subdural hygroma on the right frontal lobe.

\section{Discussion}

We present a case report of an adult with acute viral encephalopathy. Although none of pathogenic virus genome was detected in her CSF, her clinical manifestations like fever, confusion, disorientation, uncooperation and high protein levels in CSF, supported encephalopathy due to viral infection as a clinical diagnosis. Because of acute inflammation via suspected viral infection we decided to treat patient with methylprednisolone pulse therapy. After corticosteroid treatment the patient recovered quickly with mild disturbance of gait.

Encephalopathy corresponds to an inflammation of the brain parenchyma caused by some infectious (mostly the viruses) and noninfectious diseases (limbic encephalitis, Rasmussen's syndrome, metabolic diseases) [1]. Acute viral encephalopathy is often associated with influenza A infection but also has been described in human herpes virus 6 (HHV6), herpes simplex virus (HSV), mycoplasma and measles [2-7]. The pathogenesis of viral encephalopathy is not entirely explained but recent studies showed that high levels of cytokines (IL-6, TNF-a), nitrogen oxides (NOx) and histiocytosis in some organs were detected as the cause of inflammation $[8,9]$.

Treatments for acute viral encephalopathy have shown much progress during the last years. Primarily, critical care management, close clinical monitoring and MRI studies are needed. Various kinds of modalities have been performed for the treatment; steroid pulse therapy, plasma exchange transfusion, therapeutic hypothermia, intravenous immunoglobulin to modulate immune-mediated neurovascular and cell injury.

Kawano et al. [10] initiated therapeutic hypothermia within 12 hours after onset may have pivotal impacts on the outcome of the patients with acute encephalopathy. Okumura et al. [11] concluded that administration of steroid within 24 hours after the onset was related to better outcome of the patients with acute encephalopathy Tabarki et al. [12] showed that in spite of the late administration of the steroids the outcome of the patients was relatively good. Kimura et al. [13] pointed in their study that after administration of 3 days steroid therapy $(1000 \mathrm{mg} /$ day) the patient was responded quickly. İn our case, the outcome was relatively good in spite of the late administration (on the second day of admission) of pulse steroid therapy (1000 mg/day).

We think that steroid pulse therapy should be considered during the treatment of the encephalopathy even in the lack of controlled studies.

\section{References}

1. Kramer AH (2013) Viral encephalitis in the ICU. Crit Care Clin 29: 621-649.

2. Lyon JB, Remigio C, Milligan T, Deline C (2010) Acute necrotizing encephalopathy in a child with H1N1 influenza infection. Pediatr Radiol 40: 200-205.

3. Kansagra SM, Gallentine WB (2011) Cytokine storm of acute necrotizing encephalopathy. Pediatr Neurol 45: 400-402.

4. Gika AD, Rich P, Gupta S, Neilson DE, Clarke A (2010) Recurrent acute necrotizing encephalopathy following Influenza $\mathrm{A}$ in a genetically predisposed family. Dev Med Child Neurol 52: 99-102.

5. Neilson DE, Adams MD, Orr CM, Schelling DK, Eiben RM, et al. (2009) Infection-triggered familial or recurrent cases of acute necrotizing encephalopathy caused by mutations in a component of the nuclear pore, RANBP2. Am J Hum Genet 84: 44-51.

6. Kim JH, Kim IO, Lim MK, Park MS, Choi CG, et al. (2004) Acute necrotizing encephalopathy in Korean infants and children: imaging findings and diverse clinical outcome. Korean J Radiol 5: 171-7.

7. Weng WC, Peng SS, Lee WT (2010) Acute necrotizing encephalopathy of childhood with spinal cord involvement: a case report. J Child Neurol 25: 1539-1541.

8. Kawashima H, Watanabe Y, Ichiyama T, Mizuguchi M, Yamada N, et al (2002) High concentration of serum nitrite/nitrate obtained from patients with influenza-associated encephalopathy. Pediatr Int 44: 705-707.

9. Kawashima H, Watanabe Y, Morishima T, Togashi T, Yamada N, et al. (2003) NOx (nitrite/nitrate) in cerebral spinal fluids obtained from patients with influenza-associated encephalopathy. Neuropediatrics 34: 137-140.

10. Kawano G, Iwata O, Iwata S, Kawano K, Obu K, et al. (2011) Determinants of outcomes following acute child encephalopathy and encephalitis: pivotal effect of early and delayed cooling. Arch Dis Child 96: 936-941.

11. Okumura A, Mizuguchi M, Kidokoro H, Tanaka M, Abe S, et al. (2009) Outcome of acute necrotizing encephalopathy in relation to treatment with corticosteroids and gammaglobulin. Brain Dev 31: 221-7.

12. Tabarki B, Thabet F, Shafi AS, Adwani N, Chehab M, et al. (2013) Acute necrotizing encephalopathy associated with enterovirus infection. Brain Dev 35: 454-457.

13. Kimura E, Goto H, Migita A, Harada S, Yamashita S, et al. (2010) An adult norovirus-related encephalitis/encephalopathy with mild clinical manifestation. BMJ Case Rep 2010. 